\title{
The Instrumentalisation of Private International Law: quo vadis? Rethinking the "Neutrality" of Private International Law in an Era of Globalisation and Europeanisation of Private International Law
}

Private International Law is known as a very abstract, legal-technical and inaccessible discipline. Yet it is striking that PIL issues are conspicuously often interwoven with a number of heated, topical socio-legal debates, see for example the debate on transnational corporate social responsibility, the debate on posting of employees from Eastern to Western Europe, the debate on residency and social-security entitlements of foreigners based on family relationships. Both where it concerns situations governed by European PIL rules and national PIL rules, the question arises what position PIL should take in the forces at play and to what extent PIL can or should still adopt a "neutral" position.

\section{PIL: esoteric ivory-tower science and/or key role in several heated and topical socio-legal debates}

Traditionally the discipline of Private International Law (hereinafter "PIL") is attributed a high ivory-tower quality; PIL is known as a very abstract, legal-technical, esoteric and even inaccessible discipline. Yet it is striking that PIL issues are conspicuously often interwoven with a number of heated, topical socio-legal debates, touching very sensitive sectors. Often these PIL issues are even so interwoven that it is necessary to realize that the regulation of the sector may eventually be determined by whether or not and how arising PIL questions are detected and how these PIL questions are dealt with.

The following, highly topical and fiercely debated subjects may serve as illustrations: the problem of transnational corporate social responsibility, in particular the liability of multinationals for human rights violations and environmental pollution outside Europe - see the discussions about this partly further to the several cases instituted against Shell ${ }^{1}-$; the problem of posting of employees from Eastern Europe to Western Europe - see the discussions about this further to the controversial original proposal of the Services Directive and, more recently, some startling rulings of the Court of Justice ${ }^{2}$; or also the problem of residency and social-security entitlements of foreigners based on family relationships - see the recent discussions about family migration, in particular the amendment to the Family Reunification Directive: although at first glance the role of the discipline of PIL in discussions about how these subjects should be regulated may seem rather modest, on further consideration it turns out to be crucial how the PIL questions that can be recognised are answered. So, eventually, it is, in first instance, PIL rules in respect of jurisdiction and applicable law that determine to what extent and on what basis a European parent company and its non-European subsidiary can be sued in an EU country under civil law and, thus, to what extent multinationals must actually take notice of certain rules; and, eventually, it is, in first instance, PIL rules that determine which employment conditions must be respected in case of international posting and hence to what extent competition on employment conditions is possible; and, eventually, it is, in first instance, PIL rules that determine to what extent international marriages, parentage relationships etc. can be considered valid, and hence could form the building block for entitlements to rights of residence, child benefit etc. In all aforementioned subjects PIL unquestionably forms an important, if not decisive, but in any case guiding link; on further consideration the relevance of PIL each time manifestly emerges and it turns out that PIL can even act as a gatekeeper, or, as I

\footnotetext{
${ }^{1}$ See the case Milieudefensie et al. v. Shell (the Netherlands), and Kiobel v. Royal Dutch Petroleum Co (USA). See the discussions on the activities of UN-Special Representative John Ruggie to develop "Guiding Principles on Business and Human Rights". On this theme, see, recently, e.g. L.F.H. Enneking, Foreign Direct Liability and Beyond, Eleven International Publishing 2012 and some other recent publications of Enneking, to be found on http://papers.ssrn.com/sol3/cf_dev/AbsByAuth.cfm?per_id=694160
}

${ }^{2}$ EC Court of Justice C-438/05, 11 December 2007 (Viking), EC Court of Justice C-341/05, 18 December 2007 (Laval), EC Court of Justice C-346/06, 3 April 2008 (Rüffert) and EC Court of Justice C-319/06, 19 June 2008 (C./Luxembourg). See for an indication of discussions about this http://www.etui.org/Topics/Social-dialogue-collective-bargaining/Social-legislation/The-interpretation-bythe-European-Court-of-Justice . For an analysis of PIL-aspects, see http://papers.ssrn.com/sol3/papers.cfm?abstract_id=1534024 
called it elsewhere, can exercise a hinge function. ${ }^{3}$ Sometimes PIL even functions as a hinge between other legal branches. ${ }^{4}$

Insofar as policy-makers and authorities are aware of the hinge function of PIL, they may want to try to influence the way PIL rules are enacted and applied: for policy makers with an eye for the importance of PIL in the aforementioned debates the step may be small from recognising the importance of PIL rules to attempting to bend the PIL rules to their own will, as a function of the desired political outcome. The conviction may emerge that PIL may be conducive to achieving political targets that are basically associated with other fields. Paradoxically, a growing awareness of the importance of PIL could trigger tendencies to neglect, absorb, incorporate, or, at the very least, model PIL from the perspective of other fields or political objectives in these fields. Thus, attempts could be made to instrumentalise PIL - in the end by ignoring PIL. For legal subjects - e.g. multinationals that want to profit from differences in legal systems by operating in a country where the rules are less strict as regards environmental protection, safety regulations etc. or where the rules are not being implemented, or internationally operating companies that want to profit from differences in labour law between EU countries by letting foreign workers come over to the country where the production takes place and the work is carried out, or companies that want to reduce their labour costs by outsourcing labour and by moving the production process to low-wage countries - it can in turn be tempting, when realizing which PIL rules apply in a certain field, to use or take advantage of current PIL rules in a clever manner, if and to the extent those PIL rules leave room for them to do so.

Recent developments show that PIL is indeed, occasionally, used and instrumentalised in a policy-related way: the recognition of the importance of PIL and the interaction of PIL with other disciplines seems indeed, occasionally, to have an impact on PIL and to result in a specific use of PIL rules when PIL functions as a hinge. The question arises however how this phenomenon of instrumentalisation of PIL must be valued from the perspective of PIL: recognition of ongoing dynamical developments raises a number of fundamental questions in respect of essential characteristics of PIL and the interaction of PIL with other branches of law. What position should PIL assume towards the forces that are currently at play and towards the attempts to instrumentalise PIL in one way or another? To what extent is PIL entitled to a neutral and independent role, and to what extent can PIL be "neutralised" where it offers resistance? To what extent is it desirable, legitimate and feasible to make PIL subservient to all kinds of political policy motives which play a role at national and/or supranational level and which are often in essence located outside PIL; to what extent can PIL be made pliable and capable of being manipulated, to what extent is PIL suitable for instrumental use and must the foundations of PIL in this respect be guarded against impairment; to what extent can this be seamlessly fit into PIL theories, to what extent are there stubborn legal snags? What is the level of permeability of PIL? Is PIL the dreamed "path of least resistance" for achieving policy objectives, an ideal conductor and even a superconductor, as it were? Should PIL be passive and adjust to a role as a useful tool, a vehicle as it were, or should other disciplines rather be passive in respect of PIL rules and the internal logic applying in PIL, whereby PIL can prove itself almost immune to pressure from outside and can function independently? How far is it allowed to go in using certain margins as offered by PIL, in which way and with which arguments precisely must those PIL margins be filled in? Are there good reasons to sometimes completely ignore the discipline of PIL and are there moreover good reasons to actually mobilise the discipline of PIL in certain situations and not in other situations or to fill in the margins in one situation in a completely different way than in other situations?

\footnotetext{
${ }^{3}$ See V. Van Den Eeckhout, "The ill-fitting hinge. PIL as turning wheel of the legal position of foreign nationals" (Het schurend scharniertje. Ipr als draaischijf van de rechtspositie van vreemdelingen), Rechtskundig Weekblad, 1995-96, p. 33-40, see also many later publications in which I have elaborated this. On this theme, see recently, in Belgium, J. Verhellen, Het Belgisch Wetboek IPR in familiezaken: wetgevende doelstellingen getoetst aan de praktijk, Brugge: Die Keure 2012, 513 p.

${ }^{4}$ For example, between family law and migration law: the outcome of a dispute of PIL could form the link between on the one hand rules concerning family law, and on the other hand rules of migration law; rules of PIL do not stipulate whether or not married partners qualify for family reunification - these rules are by their nature to be classified as rules of migration law; nevertheless rules of PIL are very important when defining the notion of "married partner" and therefore determining a person's public legal claims. In other words, it is not the field of PIL that determines whether one can ascribe public legal claims based on certain family relationships or not. Rather when a decision in an area of public law as been taken, PIL rules are crucial in the evaluation of public legal claims based on family relationships with an international dimension.
} 


\section{Recent developments appealing to PIL}

\section{II.A. PIL: coming from a dogma of "neutrality" ...}

Under the influence of the German PIL scholar Von Savigny, continental European PIL has of old been set up as a neutral and apolitical reference system: the classical PIL paradigm implies that, independent of any legal political consideration or policy objective, the law applied to an international legal relationship is the law most closely connected to that legal relationship. Modern trends have by now also entered continental European PIL, trends such as honouring the principle of party autonomy, the favour principle, the protection principle, trends to take into account rules of semi-public law - whereby one sometimes speaks of manifestations of "governmental interest analysis". ${ }^{5}$ Where these trends have gained acceptance, PIL has in various ways rid itself of the dogma of neutrality, albeit mostly still in a rather modest manner.

\section{II.B. ... on implicit and explicit instrumental use of PIL ...}

\section{B.1. The EU as a new actor in PIL: an explicit form of instrumentalisation of PIL}

But moreover: fairly recently the sensational development of the Europeanisation of PIL has taken place. ${ }^{6}$ In this process of Europeanisation PIL rules are increasingly being formed at European level instead of traditionally at national level. In this way the PIL of EU countries is increasingly of European origin. Where European institutions get involved in PIL, PIL is (also) assessed in the light of European objectives such as promoting the European freedom of the free movement of persons, non-discrimination of EU citizens, European citizenship rights etc. After all, the promulgation as such of PIL regulations seems to be (also) inspired by the purpose of stimulating European freedoms, in the first instance by increasing predictability and foreseeability by harmonising the PIL rules; moreover, specific rules of those regulations appear to have been explicitly promulgated with a view to specific policy objectives - for instance Article 7 Rome II Regulation whose theme is the fight against international environmental pollution. ${ }^{7}$ Moreover, both the interpretation of the rules of those regulations by the Court of Justice ${ }^{8}$ and the testing of the conformity of national PIL rules with European law ${ }^{9}$ take place (also) with a view to the promotion of European objectives, whereby the European fundamental freedoms play an important role. In this process of Europeanisation PIL is thus made instrumental to "European" objectives, by which the character of "neutrality" seems to get lost in a rather radical way.

In short, in the context of the Europeanisation of PIL there currently indisputably takes place an impressive, far-reaching and fairly explicit and intensive form of instrumentalisation of PIL: the very phenomenon of the Europeanisation of PIL is illustrative of the "discovery" of PIL by European institutions as a discipline that "matters" - particularly when it comes to encouraging the exercise of European freedoms, such as the free movement of persons - and it is also illustrative of the application of PIL by many policymakers and of the occasional attempts to use PIL as a policy instrument for achieving objectives beyond the scope of PIL itself.

\section{B.2. Manifestations of instrumentalisation of PIL also before and outside the process of Europeanisation of PIL \\ But the phenomenon of instrumentalisation of PIL did not start with the phenomenon of Europeanisation of PIL and is currently neither restricted to that specific context: this process of instrumentalisation took de facto already, incidentally, place earlier in an implicit or explicit manner - PIL had in that sense already "lost its innocence" - and moreover the process of instrumentalisation also occurs currently independently of the process of Europeanisation of PIL. After all, still prior to the process of Europeanisation of PIL an example}

${ }^{5}$ On these evolutions, see e.g. recently Th. M. de Boer, "And the winner is ...? Hoe het afliep met de grondslagenstrijd in het IPR", in A.A.H. van Hoek e.a. (red.), Offerhauskring vijftig jaar. Jubileumbundel ter gelegenheid van het vijftigjarig bestaan van de Studiekring "Prof. Mr.J. Offerhaus", Boom Juridische Uitgevers 2012, p. 35-44.

${ }^{6}$ Following the Treaty of Amsterdam (1997) which, according tot Article 65 (b) of the EC Treaty, gave the Community competence to take measures to promote the compatibility of conflict of law rules applicable in the Member States in so far as was necessary for "the proper functioning of the internal market".

${ }^{7}$ See about this provision e.g. E. Guinchard and S. Lamont-Black, "Environmental law - the Black sheep in the Rome II's drive for legal certainty? Article 7 of Regulation (EC) No. 864/2007 on the Law Applicable to Non-Contractual Obligations in context", Environmental Law Review 2009, 11 issue 3, p. 161-172.

${ }^{8}$ See e.g. the Hadadi ruling (C-168/08) in which the Court of Justice interpreted an article of the Brussels IIbis Regulation.

${ }^{9}$ See the case law of the Court of Justice in international law on names and in international company law. 
of the enactment, by European institutions, of PIL rules with a view to specific European policy objectives could already occasionally be spotted - for instance the Posting Directive $\mathrm{e}^{10}$; and also national legislators and government bodies already incidentally gave in to the temptation to instrumental use of PIL rules, even before the process of Europeanisation of PIL started. ${ }^{11}$ A recent example illustrating the dynamics of the 'discovery' of PIL at the Dutch national level is the attempt to base rules of international marriage law on migration targets. ${ }^{12}$ It is remarkable for that matter how much these dynamics contrast with the European trend to model PIL with a view to stimulating the free movement of persons within Europe: while PIL at EU level is made subservient to the free movement of persons and develops in a liberal sense ${ }^{13}$, there are trends to be seen of evolution of this discipline at non-European level into an instrument of restrictive migration policy, ${ }^{14}$ so that in the end we can speak of a "two-track policy".

Eventually, both when considering the phenomenon of Europeanisation of PIL and when considering the enactment and application of PIL rules that have not been developed as such within the context of the process of Europeanisation, it appears how much PIL is undergoing a metamorphosis: from a discipline which presented itself traditionally as a fairly isolated discipline with its own nature PIL is becoming a discipline whose function seems to be related to policy considerations that often have their place in essence outside PIL. With this PIL seems more and more to lose the character of neutrality. PIL is challenged to leave the cocoon position in which it had traditionally nestled down. The meaning of the above for lawyers is on the one hand that PIL jurists are being tempted more than ever before to come out of their ivory PILtower, and that jurists from other fields are being tempted to delve deeper into problems of a PIL nature. But PIL is essentially still studied as an isolated discipline, set apart from other fields and their developments.

\footnotetext{
${ }^{10}$ According to the preamble, this Directive was designed both as a protective measure for employees and an economic stimulus for cross-border services within the internal market.

${ }^{11}$ See the changes made in 1998 in article 4 of the Dutch Marriages (Conflict of Laws) Act, by which the legality of consular marriages has been limited, inspired by migration policies (with an explicit reference to them). See, already in 1983, the Dutch practice of ignoring PIL rules in case of questions about recognition of foreign judgements whereby a change of date of birth was implemented - a very early practice of instrumentalisation of PIL in the relation PIL-migration law, but in a rather implicit manner - H.U. Jessurun D’Oliveira, "Crooked rectifications" (Kromme rectificaties), Ars Aequi 1983, p 663-673; for a description of various practices, see V. Van Den Eeckhout, "Private International Law: a discipline out of the wind or in the surf of fierce legal-social debates?" (Internationaal privaatrecht: een discipline in de luwte of in de branding van heftige juridisch-maatschappelijke debatten?), Tijdschrift voor Familie- en Jeugdrecht 2005, p. 236-244. For Belgium, see e.g. the presentation of P. Wautelet at the ius commune workshop 2009 of which the slides can be found at http://www.slideshare.net/patrickwautelet/ipr-en-migratierecht-botsing-dermethodes and - as already referred to above -, recently, J. Verhellen, Het Belgisch Wetboek IPR in familiezaken: wetgevende doelstellingen getoetst aan de praktijk, Brugge: Die Keure 2012, 513 p. Studying e.g. Dutch or Belgian practices in migration/PIL law matters in a European context: since the EU has enlarged its competency over immigration law and PIL and aims to unify regulations on issues as "family reunification" of non-European immigrants, interference of the EU in PIL-issues that are not purely "intracommunitarian" has become conceivable; this raises the possibility that actual tendencies in Dutchnational ways of dealing with PIL may be the precursors of future European practices. It is also conceivable that the elaboration of a "liberal" system of European PIL will undergo a "backlash" under the influence of concerns that are currently perceptible on a national level and which have the potential to influence PIL in a restrictive way. Ultimately, one could imagine (to the extent that the EU interferes with PIL in cases having "external aspects", as well as to the extent that expectations about evolutions in EU law could be based on trends in national Dutch law) that the EU's interference with PIL will be a double-track one, depending on the nature of the case - i.e. purely intracommunitarian or including external aspects.

${ }^{12}$ See the Proposal for a Bill on Marriage and Family Migration, TK 2009-2010, 32175 and, subsequently the Proposal for a Bill on Prevention of Forced Marriages, TK 2012-2013, 33488.

${ }^{13}$ The European Union has "brought in" PIL as an instrument to stimulate the freedom of movement of European citizens: the awareness that mobility of European citizens within the European Union can be influenced by the way people weigh the pros and cons of its impact on the regulation of their family life, spurs the elaboration of a liberal European PIL.

${ }^{14}$ When PIL issues involve non-European foreigners, authorities sometimes tend to use PIL rules in such a way as to prevent non-European migrants from claiming residence, social security and nationality, and so as to selectively restrict the mobility of non-European foreigners.
} 
This evokes the risk that the "discovery" of PIL by many a policy maker leads to the degeneration of PIL into a "plaything" in the hands of policy makers or government bodies and that PIL gets into a tight corner.

B.3. Questions on the governance role of PIL both in a context of Europeanisation of PIL or in a "European context", and in a general context of globalisation

Or must all this be depicted otherwise, in the sense that precisely here the (potential) force of PIL appears to emerge? Can it even be presented such as if precisely in these dynamics it appears that a regulating role can be assigned to PIL - and that this creates a great potential role for PIL? If so, what is or should be the role of PIL? Which governance role is then in store for PIL, both in a context of Europeanisation of PIL and in a general context of globalisation?

By now, the role PIL rules could play in addressing situations of competing norms in a globalising world is attracting increasing international attention. In this respect a possible role of PIL in realising social justice has even already been mentioned. ${ }^{15}$ But so far, “(...) private international law has contributed very little to the global governance debate, remaining remarkably silent before the increasingly unequal distribution of wealth and authority in the world", according to Muir-Watt. ${ }^{16}$ However it is already de facto so that the manner in which PIL is regulated ${ }^{17}-$ and the level ${ }^{18}$ at which this happens - has in any case an effect on, for instance, the possibilities for victims of international environmental pollution (pollution which has occurred

${ }^{15}$ See, for example, the Guest Editorial by H. Muir-Watt (published on

http://conflictoflaws.net/2008/guest-editorial-muir-watt-on-reshaping-private-international-law-in-achanging-world/) as well as her call for studying PIL as 'Global Governance', published in H. Muir-Watt, Private International Law Beyond the Schism, Transnational Legal Theory 2011, 2(3), p. 347-427.

16 “ $(\ldots)$ it does mean that private international law as the constitution of private transnational governance needs to abandon the conceit of political neutrality - to the extent that neutrality is understood as an apology or a screen that prevents it from dealing head-on with the global expressions of non-state power -, and harness its tools to the protection of the planetary commons", still according to Muir-Watt in H. Muir Watt, "Private International Law Beyond the Schism", 2012. Cfr. also earlier literature (referred to also by MuirWatt) such as several publications of R. Wai (see for several publications of R. Wai

http://papers.ssrn.com/sol3/cf dev/AbsByAuth.cfm?per id=114304) and R. Michaels (see for several publications of R. Michaels http://papers.ssrn.com/sol3/cf dev/AbsByAuth.cfm?per id=105373); see also e.g. J.P. Romano, "Le droit international privé a l'épreuve de la théorie kantienne de la justice, Festschrift für Ivo Schwander, Zürich/St Gallen, 2011; Joerges project 2011, 2 Transnational Legal Theory.

${ }^{17}$ Including leaving possibilities of instrumental use of PIL rules by the legal subjects (both companies and natural persons). As regards instrumental use of PIL rules by companies, the problems of international labour law and the problems of liability of multinationals are topics which are both perfectly suitable as case studies exploring the role of PIL rules in decisions on whether to permit companies to take advantage of differences between legal systems - this moreover both in a European and a non-European context. In the words of Jessurun D’Oliveira (Book review, Tijdschrift voor milieuaansprakelijkheid 1997, p. 77-79): “There are (...) polluters who intentionally set up the locus damni abroad. In this respect one can think of the many nuclear power stations situated along borders, but also of situations like Bhopal, which are not dealt with in this monograph, whereby dangerous production processes are located in cheap countries, countries where not only labour, but also lives are cheap." See on these issues also http://www.slideshare.net/vvde/choice-andregulatory-competition-rules-on-choice-of-law-and-forum

${ }^{18}$ At supranational (European or non-European) or national level. Earlier I already pointed at a number of chances and risks that arise in case of European regulation of PIL, viewed from the perspective of stimulation of human rights and protection of weaker parties, see V. Van Den Eeckhout, "Competing norms and European Private International Law. Sequel to "Promoting Human Rights within the Union. The Role of European Private International Law" ' (second contribution to the Refgov project, see http://refgov.cpdr.ucl.ac.be under "Publications", "Fundamental Rights", "FR20" and also http://papers.ssrn.com/sol3/papers.cfm?abstract_id=1259334), in which I have asked myself in an exploratory manner questions about finding either the "regulatory", or the "liberalising" role of PIL rules if one has to do with competing norms: the central question was whether there is a need for a central European regulator in the regulation of PIL issues; should regulation of PIL issues at European level be welcomed, if one wants to avoid the "risks of unregulated competition" and if one wants to increase the level of human rights protection within the Union?). In that respect I also already briefly examined the question of any "preconditions" to be created - e.g. in the field of unification of substantive law. 
both inside and outside Europe) for having recourse against European multinationals or also on the mobility of persons both inside Europe and from outside Europe to Europe, and that pressure is currently exercised from various sides on PIL, with the mobilisation of PIL as a policy instrument. Moreover, in this respect trends can at many places be seen towards dealing differently with PIL rules when they apply to European situations than when they apply to non-European situations. ${ }^{19}$ Questions arise as regards future developments of PIL, both where it concerns European PIL ${ }^{20}$ and PIL of EU Member States which is still of national origin. In the current situation, PIL is in an interplay of forces. ${ }^{21}$ Occasionally, "old" and "new" PIL incentives match each other well but, at other times, they are in conflict. ${ }^{22}$ Sometimes European fundamental freedoms themselves also seem to exercise an internally contradictory effect on PIL rules - see the problems of international posting and the pressure in that respect from the freedom of movement of services and the freedom of movement of persons. All in all, both where it concerns situations governed by European PIL rules and where it concerns situations that are not (yet) governed by European PIL rules - and also both where European fundamental freedoms are at issue and where that is not the case - the question arises what position PIL should take in the forces at play and to what extent PIL can or should adopt a "neutral" position.

II.C. ... resulting in questions of the "neutrality" of PIL in a dual sense: neutral PIL versus nonneutral PIL and neutral-conducting, neutralised PIL that serves as a "path of least resistance" versus PIL that offers internal resistance to pressure from outside

When answering the question of the level of neutrality of PIL, it should be kept in mind that the term "neutrality" could be understood in two senses.

In the first place we can speak of the neutrality content of PIL in the following sense: to what extent is there neutral PIL in the classical PIL sense of the word neutrality as already briefly mentioned above, whereby it in essence concerns the content of substantive neutrality: neutral PIL in the sense of the most closely connected law versus modern PIL trends such as party autonomy, favour principle etc. Or also, is PIL neutral

${ }^{19} \mathrm{Cf}$. the trend already to be recognised towards a "double-track policy" in international family law, when comparing European international family law with Dutch international family law, just as in international company law, when comparing Dutch international company law applying to EU companies versus Dutch international company law applying to non-EU companies. In international labour law for instance - where European courts apply the Rome Convention to all international legal relationships - the question can be raised to what extent a provision as Article 6 Rome Convention might be interpreted differently when it concerns "European situations" - in which European fundamental freedoms are important or it concerns EU employees - from when it concerns "non-European situations".

${ }^{20}$ See e.g. J. Meeusen, "Instrumentalisation of private international law in the European Union: towards a European conflicts revolution? European Journal of Migration Law 2007, 287-305; M. Fallon, P. Lagarde and S. Peruzzetto (eds.), Quelle architecture pour un code européen de droit international privé 2011 ; M.-P. Weller, "Anknüpfungsprinzipien im Europäischen Kollisionsrecht: Abschied von der "klassische" IPRDogmatik?" Iprax 2011/5. See e.g. very recently also R. Babayev, Choice of the applicable law and equal treatment in the European Union, Doctoral thesis Durham University 2012: in his doctoral research, Babayev explores whether and how the EC non-discrimination principle on grounds of nationality affects the choice of the law applicable to cross-border disputes. Within this framework I myself point, as an illustration, at questions which currently arise in the interpretation of Article 7 Rome II Regulation specifically in the context of liability of parent companies and their foreign subsidiary for environmental damage caused outside Europe; at questions that currently arise as regards the relation of European PIL rules - incorporated into treaties or in regulations, in the form of rules governing the choice of law (which themselves are neutral or express principles as the protection principle, the favour principle etc.) or rules of immediate applicationto European fundamental freedoms or the country of origin principle, such as Article 6 Rome Convention in relation to the European fundamental freedoms, this both as regards the question of filling in the margins which this article offers (see in this context e.g. the Schlecker case (C-64/12) about the escape clause of Article 6 Rome Convention) and as regards a possible test of the result of the application against conformity with European law.

${ }^{21}$ Cf. e.g. the discussions within international labour law about the degree in which the principle of the most closely connected law, the protection principle or the favour principle must be worked out and their relation to European policy objectives in respect of promoting mobility of persons and freedom of movement of services.

${ }^{22}$ See about this already V. Van Den Eeckhout, "Promoting Human Rights within the Union: the Role of European Private International Law”, European Law Journal 2008, 105-127. 
in the sense that PIL rules are supposed to result in the application of the legal system that is 'most closely connected' in any case - following on from the 'neutral PIL' as expounded by Von Savigny?

Subsequently, it can however also be indicated to what extent neutral PIL exists in the more physical sense of the word neutrality: it concerns then the neutrality or lack of neutrality of PIL as a mechanism; in that case the point is to examine to what extent PIL is a neutral conductor, namely neutral in relation to attempts, from outside, to let policy objectives existing in other disciplines be "conducted" via PIL - and in that way to let "current" be transmitted. In other words it concerns the resistance quality of PIL against pressure from outside, or the question to what extent internal resistance in PIL opposes making itself available for conducting some or other policy objective. Still differently formulated, it concerns the question to what extent any PIL doctrines are or can be neutralised or to what extent PIL turns out to be immune for pressure from outside. Or: is PIL neutral in the sense that PIL is apparently unable to resist attempts to use this branch of law instrumentally and to mould it into a shape that best suits the result needed?

When investigating the neutrality content of PIL in the first sense mentioned above, it concerns, as it were, an analysis within PIL and a search for the characteristic properties of PIL within the cocoon of PIL - an analysis of the foundational battle within PIL. When investigating the content of neutrality of PIL in the second sense, it concerns on the contrary an analysis of the pressure from outside on PIL, the attempts to instrumentalise PIL. In that case too it concerns in essence a search for the characteristic properties of PIL, but then actually the characteristic properties of PIL in relation to attempts to influence it from "outside".

It is actually very important to distinguish the two types of neutrality and to see them at the same time in their mutual relationship: it must for instance be recognised that non-neutral PIL in the first sense can go together with both neutral PIL and non-neutral PIL in the second sense: a way to conduct political objectives via PIL - and to make PIL in this way, as it were, neutral in the sense of without resistance and "conductive" - can be to take advantage of modern trends in PIL and to realise and negotiate the objectives by making use of trends as the protection principle, the favour principle etc. or to hold onto the old paradigm. Radically ignoring PIL can for that matter, ultimately, also be a possible way of instrumentalising PIL, as already noted before. Well then, it is conceivable that the instrumentalisation of PIL by radically ignoring it (and hence completely disconnecting from PIL) results in leaving more freedom of movement in PIL itself, in having more room for "own" developments in PIL itself (which may lead to the result that PIL will have more scope for going its own way); but it must then be kept in mind that the result of such action can easily be that for a number of persons seeking justice the outcome of PIL rules becomes an "empty shell". For instance, when the result of the application of PIL rules is completely disconnected from migration law ${ }^{23}$, favor matrimonii trends in PIL $^{24}$ might become (still) stronger than is currently the case, but it must then be realised that in case of such action obtaining a for PIL legally valid marriage can be without meaning and an empty shell when an entitlement to family reunification is at stake.

III. Present state of affairs: need for contemplation and reflection, for further and systematic analysis of neutrality and instrumentalisation - a need for an analysis of the opportunity, legitimacy, effectiveness and side effects of assigning an instrumental function to PIL.

In the current state of the law various practices and procedures seem to be established "à la carte". Also in view of the casuistic nature of the ongoing developments, there is a great need for an analysis of the opportunity, legitimacy, effectiveness and, if possible, side effects of assigning an instrumental function to PIL.

An examination of the current state of affairs presupposes a variety of key questions, including the following: to what extent does PIL currently present itself, as it were, as an unguided missile which functions as a plaything without any internal resistance, whereby in a system of pick and choose some or other PIL technique is used, whereby the margins of some or other PIL rule are selectively filled and a case-to-caseapproach applies? Is PIL currently developing, as it were, in all kinds of directions and are there large

\footnotetext{
${ }^{23}$ Entitlements to family reunification would for instance become completely independent of the outcome of the application of PIL rules in respect of considering an international marriage valid or invalid.

${ }^{24}$ It must be noted for that matter that a "favor" disposition such as favor matrimonii does not necessarily have to appear to be in contradiction with the trend which I call 'restrictive association with PIL': trends towards considering a marriage as much as possible valid can sometimes also be pushed through so strongly that in its effect on other areas of law a liberal PIL regulation works out negatively for those concerned. See my contribution 'The socialization of Private International Law. Developments at the beginning of the $21^{\text {st }}$ century’, Migrantenrecht 2002, p. 144-158 for examples in respect of marriage and parentage.
} 
inconsistencies, or is that what is taking place in various subfields well-reasoned, at least accountable? Can PIL be unlimitedly modelled? Can PIL be called up as a "deus ex machina" - with the possible consequence of differences in the way in which various authorities consider the same marriage the one time valid, the other time invalid ${ }^{25}$ ? Which chances and risks can be recognised when the ongoing dynamical developments are considered? Does or does not PIL fulfil in the ongoing developments the potential role ascribed to PIL in respect of bringing about social justice? But what is then precisely the role of PIL or what could/should it be? Suppose the dogma of "neutral PIL" is abandoned, which precise objectives might or could then be of importance in the instrumentalisation of PIL and can be "conducted" via PIL - what interests can or may PIL serve at the end of the day? -, and how should its relative weight be estimated? And how precisely can PIL facilitate or complicate the achievement of these objectives?

Answering the aforementioned questions requires both an analysis de lege lata and de lege ferenda. It requires an analysis which will involve - in various subfields and as regards the three classical subquestions of PIL (questions of jurisdiction, applicable law and recognition/enforcement) - in a multidisciplinary approach various other disciplines in addition to PIL. It requires a very legal-technical analysis which has at the same time an eye for legal-political considerations. Both a descriptive and a critical analysis are needed. Old discussions in PIL - in respect of the Savignian paradigm of neutrality of PIL, the need for protection of weak parties, influence of semi-public law, influence of American tendencies and neo-statutism ${ }^{26}-$ could be $^{2}$ analysed in this respect from a new angle and in the light of the current developments.

If PIL is studied as a discipline that is not isolated from other branches of law but that interacts with these other branches; if it is recognised how PIL is occasionally 'used' as a vehicle to achieve policy objectives or may at least make a difference; if it is revealed that PIL may act as a hinge, and if it is recognised that interaction with PIL may make a difference in various debates in which PIL initially did not seem to be an essential factor, then, the burning question arises whether - and if so how - PIL should be "used" in the future and, in short, what the attitude should be towards future PIL developments.

\section{$\underline{\text { IV. A possible methodological approach }}$}

\footnotetext{
${ }^{25}$ See the formulation used by J. Verhellen, "International family law and migration policy: PIL as deus ex machina?" note to RvV 24 November 2009, tijdschrift@ipr.be 2010 (1), 152-155. See also the practices briefly mentioned by me earlier of assessing international parentage relationships, whereby alternately this or the other outcome was arrived at (sometimes with, sometimes without mobilising PIL or by filling in the margins offered by PIL rules now in this way, then in another way), see V. Van Den Eeckhout, "Your children are not your children ... within the meaning of Article 7 General Child Benefit Act" (Uw kinderen zijn uw kinderen niet ... in de zin van artikel 7 AKW), Tijdschrift voor Familie- en Jeugdrecht 2001, p. 171176.

${ }^{26}$ So that a new look can be cast on these discussions and these discussions can be weighed in the light of the dynamical developments that are indicated here - for instance about rules of immediate application in PIL: with the issue of rules of immediate application one immediately finds oneself in the old, but classical discussion about "neo-statutistic" PIL versus neutral "Savignian" PIL; - when this is moreover situated in the subject of the European freedoms (whereby for instance application of rules of immediate application sometimes seem to clash with the European freedom of movement of services) one immediately finds oneself in a very topical discussion about the impact of European freedoms on PIL, within which the old discussion about neo-statutistic PIL versus neutral Savignian PIL again emerges. See also the question of issuing rules governing the choice of law (and the possible stretching of those rules) which intend to protect weak parties: with the question of the protection of weak parties such as employees) one immediately finds oneself in the discussion about neutral versus non-neutral PIL; this e.g. in combination with the European non-discrimination principle and the freedom of movement of persons again results in interesting points of discussion. And see also the possibilities that are offered by viewing PIL in its "hinge role" in discussions about the relation between the doctrine of human rights and PIL: when it is recognised that PIL sometimes plays or can play a hinge role and when it is recognised that the way in which that hinge role is filled in can be significant in discussions about the impact of and respect for human rights, this prompts to asking fundamental questions about the role of PIL; does PIL deserve a "neutral" role in discussions about impact of human rights? Does PIL sometimes keep, as it were, "the door closed" for people seeking justice or is legal protection "allowed through" via PIL. Are human rights perfectly "conducted" in and along PIL (are they conducted through/out/...)? Should one be alert for attempts to "neutralise" the impact of human rights by dealing in a particular way with PIL? etc.
} 

studies

It is possible to analyse PIL from the aforementioned perspective in an exploratory manner by selecting a number of well-chosen case studies which when analysed each on itself and in a combined analysis can give in every way more insight. Several themes could, thus be the subject of further study in the form of case studies - I refer myself to the three themes mentioned above: PIL aspects of social corporate responsibility, PIL aspects of labour law, including international posting and PIL questions that arise in the interaction between migration law - in the broad sense of the word - and international family law. As said, tensions can be felt and lively dynamics exist in each of these three areas, which raises questions about the place of PIL amidst those tensions and forces, particularly about the "neutrality" of PIL.

IV.B. Exploratory study on the basis of case studies which show all kinds of similarities as well as differences

The case studies can be selected such that both a number of similarities and differences can be pointed out between them. When studying each of them in greater detail from the perspective of neutrality and instrumentalisation and when juxtaposing the results of each of them, it may be possible to formulate a beginning of a conclusion about the question to what extent general points of view ${ }^{27}$ can be developed or to what extent per subfield of PIL/per "context" in which a PIL issue presents itself separate points of view must be developed and to what extent differentiation is needed - in this way, put together, the analysis of the case-studies could allow to provide a coherent view. The three above-mentioned case studies run parallel/are different in respect of the following points: whether or not in the PIL subject matter the principle applies that as regards PIL one of the parties must be protected as being a structurally weak party ${ }^{28}$; whether it is about intracommunatarian situations - dealing with differences between legal systems of EU-Member sates - or (also) about extracommunatarian situations; whether or not European fundamental freedoms, internal market principles such as the country of origin principle, the principle of European citizenship, the European nondiscrimination principle make themselves felt in the subject matter - at least in specific situations; the circumstance whether the European freedoms which, where relevant, apply in the subject matter appear in the same/different sense as PIL rules; the circumstance whether, where relevant, several European freedoms make themselves felt in the subject matter which themselves push PIL rules in the same direction or not ${ }^{29}$; whether or not a dividing line exists in the subject matter between situations governed on the one hand by European rules and situations governed by non-European rules on the other hand/situations in which European rules possibly apply to all situations, but are possibly interpreted differently in situations in which European fundamental freedoms are at issue on the one hand and situations in which no European fundamental freedoms are at issue on the other hand; the circumstance whether or not the PIL regime that is in force in the subject matter is of European origin and whether, where relevant, the European rules govern all international situations or whether part of these situations is still governed by rules of national origin; whether or not - in addition to rules of applicable law - rules of PIL procedural law should also be involved in the analysis of the subject matter; whether or not human rights are at issue in the subject matter; the degree of discretion which PIL rules offer in the subject matter - the margins that can be filled.

\footnotetext{
${ }^{27}$ About the essential characteristics of PIL itself, as well as the characteristics of PIL when it presents itself in its hinge function.

${ }^{28}$ In international labour law the employee is classically considered as the weak party to be protected. In international tort law arguments exist to assign the qualification of "weak party" to victims of specific violations (of human rights) committed by multinationals. See V. Van Den Eeckhout, "Corporate Human Rights Violations and Private International Law. The Hinge-Function and conductivity of PIL in implementing Human Rights in Civil Proceedings in Europe: a Facilitating Role for PIL or PIL as a Complicating Factor?", available at http://papers.ssrn.com/sol3/papers.cfm?abstract id=1895690

${ }^{29}$ See e.g. in international labour law the tension caused by the impact from the freedom of movement of persons and - in a rather opposite sense, so it seems - the freedom of movement of services. See V. Van Den Eeckhout, "International Labour Law Oppressed between Freedom of Movement, Freedom of Services, Freedom of Establishment and Non-Discrimination - Some Considerations from a Private International Law Perspective on the Recent Judgments Viking, Laval, Rüffert and C./Luxembourg, Third contribution to the Refgov project, see http://refgov.cpdr.ucl.ac.be under "Publications", "Fundamental Rights", FR26.
} 
Ultimately, a scrutiny of the case studies may enable a general view to be developed on the role, resistance levels and individual character of PIL, leaving open the possibility that the conclusion might be that a distinction should be made based on the characteristics of each case study: for example, a distinction based on whether PIL rules are invoked in an intra-Community context - for instance, to what extent companies ${ }^{30}$ can or cannot invoke the freedom of establishment and the freedom to provide services -, or a distinction based on the question whether or not the pressure exercised by European freedoms on PIL rules drives PIL in the same direction. At least, the relevant factors and issues could, thus, be identified.

\section{In conclusion: a role for PIL in achieving social justice?}

It will be clear that both in the analysis of each of the three aforementioned areas of research and in a more synthetic dissection legal-political questions also play a role in the background when trying to answer the legal-technical questions: where research goes further than a description and goes over to valuation and formulation of proposals de lege ferenda, a researcher will out of necessity also be faced with the problem of legal-political choices. The terms that are sometimes used when describing the role of PIL, the issue of PIL rules and the manner in which PIL is dealt with in some debates are quite telling: PIL is sometimes attributed a "collaborating" or "complicit" role. ${ }^{31}$ Where there is resistance from PIL against deploying PIL rules for instrumental use or where, when reasoned from the perspective of PIL, a result and dynamics seem to emerge which clash with, run counter to, and offer resistance to policy objectives to which government bodies also want PIL to contribute, it ultimately concerns the subversive and oppositional nature or otherwise of PIL.

Looking at current developments and tensions - in which PIL is, ultimately, questioned on both its internal foundations and its position between other legal branches - from the perspective of "social justice" might help to evaluate ongoing developments.

"Social justice", "regulatory function", ... Questions exist on the role of private law in achieving social justice, the "regulatory function" of private law, "cosmopolitanism" in private law etc. ${ }^{32}$ - certainly in the current debate on an optional European Civil Code. In debates on social justice etc., the discipline of private international law should not be overlooked.

Looking from the perspective of social justice might be useful in establishing one's position towards current attempts to "instrumentalise" PIL in certain areas - or the lack thereof in other areas: for example, what about tendencies in the Netherlands to model PIL into an instrument of restrictive migration policy? Or what to

${ }^{30}$ E.g. in cases of international labour law or also in cases about their liability for violations of fundamental rules - the problem of corporate social responsibility.

31 And PIL itself is sometimes alleged to be "contaminated" or even "poisoned"; sometimes it is also suggested that PIL is "mutilated" or "perverted" - even if it concerns involving PIL for realising at first sight worthy objectives, such as combating environmental pollution. See e.g. http://www.publications.parliament.uk/pa/ld200304/ldselect/ldeucom/66/66we05.htm, in discussions at the time about the proposal of Article 7 Rome II Regulation, about which it can be read "It is a perversion of choice of law reasoning to mutilate the law so that it promotes the "polluter pays principle (...) Article 7 ought to be deleted."

${ }^{32}$ See e.g. the work of researchers such as Chantal Mak (for several publications, see http://papers.ssrn.com/sol3/cf dev/AbsByAuth.cfm?per_id=408351 ), Ewoud Hondius (see e.g. "Sociale rechtvaardigheid: de bijdrage van het privaatrecht", Ars Aequi 2013, p. 197-198 and his presentation on "De bijdrage van het privaatrecht aan sociale rechtvaardigheid" on May $16^{\text {th }} 2013$ at Leiden University) and Hugh Collins (for several publications, see http://papers.ssrn.com/sol3/cf_dev/AbsByAuth.cfm?per_id=339375). See also the references already made above, in footnote 16 (and other references made by Muir-Watt in her article "Private International Law Beyond the Schism") - sometimes at the intersection of private law and private international law/exploring specific issues of PIL; see in particular the work of R. Wai, already referred to above. See also several papers presented at the Conference (Duke Law School) "What is Private International Law" (November 2012). For the use of the term "Environmental social justice", see e.g. recently C. Staath and B. Wray, "Corporations and Social Environmental Justice: the Role of Private International Law", in Towards Environmental Justice, A. Duval and M.-A. Moreau (eds.), EU Working Paper Law 2012/02, EUI (European University Institute, Florence). 
think about the idea of (further) modelling PIL on a European level into a genuine instrument in the fight against international environment pollution, or into a genuine instrument to guarantee labour protection? Where should PIL "resist" outside pressure to model it, where should PIL be "subservient"?

Looking from the perspective of social justice: is PIL, in the current situation, not neutral in certain areas, in the sense that PIL is complicit to social injustice? Is there e.g. a risk that PIL is evolving in the Netherlands into an instrument to deny residence and social security claims of foreigners - and is PIL, thus, not "neutral" when it functions as a hinge between migration law and family law? Should PIL show more resistance here to pressure from outside? And to what extent can PIL be used as a power tool in the hands of multinationals - is PIL, thus, not a "neutral" discipline in issues of transnational corporate social responsibility? Can PIL instead guarantee or even further social justice, and if so how exactly can PIL rules be mobilised c.q. applied to achieve broader social justice in national and international society?

The study of the position of PIL in the three above-mentioned debates (the debate on transnational corporate social responsibility, the debate on posting of employees from Eastern to Western Europe, the debate on residency and social-security entitlements of foreigners based on family relationships) may give a picture of the potential of PIL for the advocates of (transnational) social justice. Looking from the perspective of guaranteeing c.q. achieving social justice might help in finding one's position regarding the role of PIL in these issues, including controversies on the instrumentalisation of PIL, its "neutral" character etc. The issues matter, and PIL could make a difference in these issues. Ultimately, the potential of PIL to guarantee c.q. achieve social justice in these and other areas might be high.

\author{
Veerle Van Den Eeckhout
}

(Leiden University and University of Antwerp) 